OPEN ACCESS

Edited by:

Kim Nguyen,

Purdue University Indianapolis,

United States

Reviewed by:

Christopher Anderson,

Dominican University, United States

Tiffany Steele,

Oakland University, United States

Richard Hill,

University of Detroit Mercy, United States

${ }^{*}$ Correspondence: Amy R. Betz

arbetz@ksu.edu

Specialty section: This article was submitted to

STEM Education,

a section of the journal

Frontiers in Education

Received: 02 March 2021 Accepted: 14 July 2021

Published: 27 July 2021

Citation:

Betz AR, King B, Grauer B, Montelone B. Wiley $Z$ and Thurston $L$ (2021) Improving Academic Self-

Concept and STEM Identity Through a Research Immersion: Pathways to

STEM Summer Program.

Front. Educ. 6:674817.

doi: 10.3389/feduc.2021.674817

\section{Improving Academic Self-Concept and STEM Identity Through a Research Immersion: Pathways to STEM Summer Program}

\author{
Amy R. Betz ${ }^{1 *}$, Brenee King ${ }^{2}$, Bette Grauer ${ }^{1}$, Beth Montelone ${ }^{3}$, Zelia Wiley ${ }^{4}$ and \\ Linda Thurston ${ }^{5}$
}

${ }^{1}$ College of Engineering Dean's Office, Kansas State University, Manhattan, KS, United States, ${ }^{2}$ Office of Undergraduate Research and Creative Inquiry, Kansas State University, Manhattan, KS, United States, ${ }^{3}$ Office of Research Development, Kansas State University, Manhattan, KS, United States, ${ }^{4}$ College of Agriculture Dean's Office, Kansas State University, Manhattan, KS, United States, ${ }^{5}$ College of Education Dean's Office, Kansas State University, Manhattan, KS, United States

Undergraduate research opportunities have been demonstrated to promote recruitment, retention, and inclusion of students from underrepresented groups in STEM disciplines. The opportunity to engage in hands-on, discovery-based activities as part of a community helps students develop a strong self-identity in STEM and strengthens their self-efficacy in what can otherwise be daunting fields. Kansas State University has developed an array of undergraduate research opportunities, both in the academic year and summer, and has established a management infrastructure around these programs. The Graduate School, which hosts its own Summer Undergraduate Research Opportunity Program aimed at URM and first-generation college students, coordinates the leadership of the other grantfunded programs, and conducts a series of enrichment and networking activities for students from all the programs. These include professional development as well as primarily social sessions. The Kansas LSAMP, led by Kansas State University, created a summer program aimed at under-represented minority community college students enrolled in STEM fields to recruit them into research opportunities at K-State. There has been strong interest in the program, which incorporated university experience elements in addition to an introduction to STEM research and the four-year university. In the 5 years since the program's inception, cohorts of nine to fourteen students came to K-State each year for eight-week experiences and took part in both cohort-based sessions and individual mentored research experiences. The two-fold focus of this program, Research Immersion: Pathways to STEM, has resulted in the majority of the students presenting a poster at a national conference and transferring to a STEM major at a fouryear institution. Survey results showed that the program was successful at improving STEM identity and academic self-concepts. Qualitative feedback suggested that the two parts of the program worked together to increase interest and self confidence in STEM majors but also ensured that students connect with other students and felt comfortable in the transition to a 4-year institution.

Keywords: summer research experience, community college, academic self concept, science STEM identity, STEM recruiting 


\section{INTRODUCTION}

The United States faces continued need for graduates in science, technology, engineering and math (STEM) to address national and global challenges in energy, medicine, infrastructure, computer technology and other STEM fields (The National Academy of Sciences, 2011). While the need for STEM graduates is strong, student attrition remains high in STEM degree programs (National Center for Education Statistics, 2013). Further, underrepresented minority (URM) students represent a small percentage of students completing STEM degrees (DePass and Chubin, 2008). STEM degree granting institutions have developed STEM intervention programs (SIPs) such as mentoring, tutoring, and research opportunities to improve retention through support and engagement of students, particularly underrepresented minority students (George-Jackson and Rincon, 2011). Research into the impact of SIPs is limited. Researchers have called for studies of the efficacy and impact of these programs on URM students (DyerBarr, 2013).

Undergraduate research provides students an opportunity to engage in the process of scientific discovery and get insight into what a science career might entail. Reports from students highlighted personal and professional gains, the ability to "think like a scientist" and a shift in attitude toward learning and working as a researcher (Seymour, 2004). While undergraduate research can occur during the academic year, summer undergraduate research allows for students to engage in the process full-time. Summer programs have been shown to enhance the educational experience of undergraduate students as measured by learning gains related to the research process, readiness for more demanding research and understanding how scientists work on real problems (Lopatto, 2004; Lopatto 2007). Additionally, student benefits include increased interest in their discipline, enhanced career preparation, gains in critical thinking and a shift from passive to more active learning (Seymour 2004). Summer undergraduate expereinces have been leveraged to address educational disparities across racial, ethnic and gender groups (Ghee et al., 2016). Furthermore, URM students were shown to have higher gains than a comparison group on learning items that included, ability to integrate theory and practice, understanding of science, learning to work independently and becoming part of a learning community (Lopatto 2007). Students who participated in research early in their careers were more likely to persist in STEM fields with positive gains found for first-generation students (Ishiyama, 2001; Seymour, 2004) and students from underrepresented groups (Nagda, 1998). Yet a recent report surrounding Research Experiences for Undergraduate (REU) programs showed that $91 \%$ of these programs served juniors and seniors (Langhoff, 2018).

Community colleges are poised to be an essential component in the solution to increase the representation of women and underrepresented minorities in STEM. Forty-four percent of Americans who receive bachelor's degrees in science and engineering attend community college at some point in their education (Tsapogas, 2004). Community colleges provide the most diverse student body in the United States with access to higher education, as they serve people of color, women, nontraditional students, veterans, international students, firstgeneration students and working parents (Olson and Labov, 2012). While there is a body of literature surrounding student success programs (ex. learning communities, student success courses and supplemental instruction) at community colleges, more work is needed to fully understand the impact of these interventions on community college students (Crisp, 2013). Furthermore, opportunities for community college students to participate in undergraduate research are limited, although there have been recent efforts to build, implement, and sustain undergraduate research experiences at community colleges (Patton, 2020). The program highlighted in this article is a collaboration between community colleges and Kansas State University (KSU), a four-year institution with a program goal to increase confidence and retention of students in STEM fields.

The Research Immersion: Pathways to STEM (RIPS) program is coordinated by the Kansas Louis Stokes Alliance for Minority Participation (KS-LSAMP). KS-LSAMP, funded by the National Science Foundation, aims to increase the quality and quantity of underrepresented students successfully completing baccalaureate degrees in STEM. The program includes specialized activities at critical junctures in a student's academic life cycle such as high school to college; two-year to four-year institutions; and the critical freshman-to-sophomore transition at four-year institutions. The alliance is comprised of two four-year baccalaureate granting institutions and five community colleges throughout the state of Kansas.

The conceptual framework for this project integrates three distinct and complementary theories: retention/integration theory, cumulative advantage theory, and engagement theory. Retaining more students of color at their first college to degree completion is key to improving STEM completion. Research findings provided ample evidence for targeted, programmatic efforts that not only increased baccalaureate attainment but also increased the number of STEM graduates.

Framework 1: Retention theory/integration theory: Theorists (Spady, 1970; Tinto, 1975; Astin, 1993; Tinto, 1997) hypothesized that student degree progress and completion were influenced by social and academic integration within an institution. More recent integration theories also posited other aspects of the institutional environment that play a role in retention of underrepresented students, such as climate and practices fostered by institutional agents (Nora, 2003; Hernandez and Lopez, 2004; Nora et al., 2005), in their study of the "leaking pipeline" for Latino/a college students, reviewed personal, environmental, involvement and socio-cultural factors influencing student persistence in higher education. Researchers in retention theory suggested subcomponents of retention that informed the work of this project: resilience, identity, and academic self-concept.

Academically resilient students were described as students "who sustain high levels of achievement motivation and performance despite the presence of stressful events and conditions that place them at risk of doing poorly in school and ultimately dropping out of school" (Alva, 1991, p. 19). The 
resilience construct was used by researchers to identify factors that accounted for success; also described as protective factors that moderated the influence of risk factors on outcomes. Factors that impact resilience were support (i.e. family and peer support; teacher feedback), sense of belonging, and cultural loyalty (Gonzalez and Padilla, 1997).

The development of a strong science identity has been shown to improve persistence among science majors (Chang et al., 2011) and to shape students' trajectories within scientific disciplines (Carlone and Johnson, 2007). Carlone and Johnson's (2007) model of science identity included competence, performance, and recognition. Students with strong science identities were those who demonstrated competence in the discipline, possessed the skills to perform scientific practices, and achieved recognition (from themselves and from meaningful others) as a "science person". Thus, given the high attrition rates found in STEM disciplines (Hernandez and Lopez, 2004) practitioners and policymakers needed to identify best practices that promote students' development of a stronger identity with their STEM major. A critical component to students' STEM identity development and socialization into the sciences involved being seen by relevant others as a science person (Carlone and Johnson, 2007). Being mentored, recognized, or validated as competent in science by faculty and peers helped students develop strong, positive STEM identities. Researchers also highlighted several college experiences and contexts that influence science identity development. Hurtado et al. (2009) found that undergraduate research experiences enhanced student interest in becoming a scientist, as students improved their knowledge and understanding of science (Sabatini, 1997) and developed their professional self-confidence (Mabrouk and Peters, 2000; Lopatto, 2003).

Research has shown that higher academic (rather than social) self-concept is evidenced among STEM completers and initial STEM identity played a small but significant role among completers. Sedlacek (1989) reported that a strong academic self-concept was important for URM students; Astin (1982) found that academic self-concept was related to persistence in postsecondary education for students of color. Hernandez and Lopez (2004) suggested that academic advisory staff examine academic self-concept and facilitate its development, including sensitizing faculty and staff to contribute to its development through encouragement, meaningful engagement and constructive critique and feedback.

Framework 2: Engagement theory (e.g. (Kearsley and Shneiderman, 1998)) was based upon the idea that when students were meaningfully involved in their learning through interactive and worthwhile tasks there were multiple benefits to the learner. When students were engaged they considered the activity to be personally meaningful, interest and persistence were promoted, self-efficacy was increased, and optimum academic performance was produced (Kearsley, 1997). Students who were engaged learned at high levels, retained what they learned and transferred their learning to new contexts. Therefore, diverse and engaged participants at all levels (e.g. faculty, advisors, administrators) were an essential element of program design. Researchers concerned about students' disinterest and disengagement in STEM at the postsecondary level, especially in URM students and women, argued for a shift toward studentcentered pedagogies that fostered a more supportive environment and connected classroom content to its application in the "real world" (Eagan et al., 2014; Estrada et al., 2016). Connecting content to its application in professional contexts or demonstrating its relevance to students' lives improved the STEM classroom experience (Davis and Finelli, 2007).

Framework 3: The theory of cumulative advantage (e.g. (Allison et al., 1982; Zuckerman, 1988) is especially relevant to this project because it provides a mechanism for understanding inequality across a temporal process (e.g., high school, college, lifetime). The theory posited that a favorable relative position facilitated further relative gains (DiPrete and Eirich, 2006). For example, research on the career trajectories of scientists demonstrated a pattern of growth in maintenance of inequality with respect to productivity, recognition, and performance, as early career success attracted new resources and rewards that promoted continued high levels of achievement (Allison and Stewart, 1974; Zuckerman, 1988). In education, a cumulative advantage process was "capable of magnifying small differences over time and made it difficult for an individual or group that was behind at a point in time in educational development to catch up" (DiPrete and Eirich, 2006, p. 272). Eagan and his colleagues (Eagan et al., 2013) noted that in regard to STEM students' developing science identities, cumulative advantage theory suggested that students who, prior to college, had access to particular resources or experiences (i.e., parent in a STEM career, pre-college research experiences, recognition as highly competent in STEM) that helped develop relatively stronger STEM identities early were more likely to have an even stronger relative STEM identities in the future, especially since they tended to gain greater access to those important resources and activities during college.

Research questions: There are two areas that encompass elements of these three frameworks that have existing quantitative elements instruments: Academic self-concept and STEM identity. This lends itself to two research questions that will be addressed in this manuscript:

1) Does the RIPS Summer Research Program with integrated University experiences increase academic self-concept?

2) Does the RIPS Summer Research Program with integrated University experiences increase STEM interest and STEM identity?

Since this RIPS program is unique in its focus on community college students, these research questions make a new addition to existing literature.

\section{METHODOLOGY}

Program information was advertised at community colleges and a four-year institution. Student eligibility included completion of college-level Algebra and one college-level science course with accompanying lab. As this program was designed as an 
TABLE 1 | Demographic information.

\begin{tabular}{lc}
\hline & $\mathbf{N}=\mathbf{5 3}$ \\
\hline Gender & \\
Male & $30(57 \%)$ \\
Female & $23(43 \%)$ \\
Race-ethnicity & \\
Black or african american & $3(6 \%)$ \\
Asian or asian american & $4(7 \%)$ \\
Hispanic or latino & $44(83 \%)$ \\
White & $2(4 \%)$ \\
Institutional status & \\
Community college & $41(77 \%)$ \\
Four-year institution & $12(23 \%)$ \\
Parental/guardian education & \\
First-generation & $40(75 \%)$ \\
Continuing education & $13(25 \%)$
\end{tabular}

introduction to undergraduate research, students did not need to have prior research experience. Applications included a personal statement and two letters of recommendation from STEM faculty members.

Selected students were invited to stay in on-campus housing at the four-year institution for the entirety of the eight-week program. Student participants worked in research labs between 30 and $35 \mathrm{~h}$ per week. In addition to research-focused work, students were asked to attend a seminar two times per week. This seminar time included supplemental information to enhance students' research experiences, information related to campus life at a four-year institution and time for the cohort to interact socially. The program culminates in students writing a research abstract and presenting a research poster to the KSU community.

Towards the end of the program, retrospective surveys were administered to participants and kept open for a two-week period. Surveys were entered into the online survey system, Qualtrics, and distributed via email. Follow-up emails were sent to encourage survey completion and increased response rates as the survey close date occurred after program participants had returned home from the program. Fifty-three students participated in the program from 2015-2019. Students also participated in semi-structured focus groups. The purpose of the mixed method design was to elaborate and enhance the results from the quantitative surveys (Schoonenboom and Johnson, 2017).

Survey instruments developed by the KSU Office of Educational Innovation and Evaluation (OEIE) for the RIPS program reflected the Dillman Tailored Design Method (Dillman et al., 2014) in regard to the following: 1) item development and selection, 2) use of appropriate scales, 3) layout, and 4) general questionnaire formatting for clarity and utility. The surveys were primarily utilized to assess changes in student participants' STEM interest, STEM identity, sense of belonging, resiliency, and future academic and/or career goals/ intentions. Survey items and focus group questions were carefully selected from the works of Lent et al. (1986), Hurtado and Carter (1997), Luzzo et al. (1999), and Eagan et al. (2014). Project activities took place annually and surveys were administered at the conclusion of each activity. The focus group design and analysis utilized the methodology outlined in Krueger and Casey (2009). The design of these instruments for the evaluation of this program was discussed in more detail previously (Grauer et al., 2015).

\section{RESULTS AND DISCUSSION}

Information about the demographics and overall perception of the program experience will further understanding of the results relevant to the research questions. Table 1 shows the majority of program participants (83\%) identified as Hispanic or Latino with a home institution at a community college. Additionally, $75 \%$ of students (40 of 53) identified as first-generation as defined by those whose neither parent or guardian earned a four-year degree.

Of the fifty-three students surveyed over a five-year period, forty-four submitted surveys at the completion of the program (response rate of $83 \%$ ). Participant satisfaction was high, as shown in Table 2, and all but two participants felt the program was worth their time. While participants had extremely positive experiences in the program, there is not as strong an indication that the program helped them clarify the field of interest or decide career path that is best for them.

\section{RQ1: Does a Summer Research Program With Integrated University Experiences Increase Academic Self-Concept?}

The results in Table 3, 4 demonstrate that the RIPS program increased the participants' academic self-concept. There were mean increases in all items surveyed related to academic selfconcept.

The question, "I am able to study and improve in courses that may be hard for me" had three disagrees and seven neutral responses in the before reflection but no negative or neutral responses in the after reflection of the summer program. No other question moved that many negative or neutral responders to positive responders.

Focus groups were also held at the end of each summer session for cohorts 1,2, and 3 to better illustrate and enhance the qualitative data. The focus group questions are provided in Table 5.

The quantitative changes in the responses to the question, "I am able to study and improve in courses that may be hard for me" are further explained by the response to question four in the focus group which is synthesized in Table 6. A major theme that arose in the discussion of question four for every cohort was the need for patience/persistence/determination.

Looking directly at student quotes, students tie this patience and persistence to the value of hard work compared to innate ability.

"It takes patience. You can't say 'I'm not smart enough to be a scientist."' (Cohort 1)

"Even though you're failing, you can't get something right, you still have to keep at it because all your hard 
TABLE 2 | Overall program experience $N=44$.

\begin{tabular}{|c|c|c|c|c|c|c|}
\hline Question & $\begin{array}{l}\text { Strongly } \\
\text { Disagree }\end{array}$ & Disagree & $\begin{array}{l}\text { Neither } \\
\text { Agree or } \\
\text { Disagree }\end{array}$ & Agree & $\begin{array}{l}\text { Strongly } \\
\text { Agree }\end{array}$ & Mean (SD) \\
\hline I felt satisfied with the way the RiPS summer program was conducted ${ }^{a}$ & 2 & 1 & 2 & 7 & 20 & $4.31(1.15)$ \\
\hline The RiPS summer program met my expectations ${ }^{a}$ & 2 & 1 & 1 & 10 & 18 & $4.28(1.11)$ \\
\hline I found the RiPS summer program to be worth my time and effort ${ }^{a}$ & 2 & - & - & 6 & 24 & $4.56(1.01)$ \\
\hline $\begin{array}{l}\text { The RiPS summer program encouraged me to meet with staff, faculty or others about } \\
\text { my STEM interest and education }\end{array}$ & 2 & - & 1 & 20 & 21 & $4.32(0.91)$ \\
\hline $\begin{array}{l}\text { The RiPS summer program encouraged me to get involved with activities and } \\
\text { organizations related to my STEM interests }\end{array}$ & 2 & - & 4 & 19 & 19 & $4.20(0.95)$ \\
\hline $\begin{array}{l}\text { The RiPS summer program faculty and staff provided me with feedback about my } \\
\text { academic work }\end{array}$ & 2 & - & 5 & 17 & 20 & $4.20(0.98)$ \\
\hline $\begin{array}{l}\text { The RiPS summer program faculty and staff believed in my potential to succeed as a } \\
\text { scientist }\end{array}$ & 2 & 1 & 1 & 14 & 26 & 4.39 (0.99) \\
\hline $\begin{array}{l}\text { The RiPS summer program faculty and staff recognized my achievements in STEM } \\
\text { education }\end{array}$ & 2 & 1 & 4 & 17 & 20 & $4.18(1.02)$ \\
\hline The RiPS summer program clarified which STEM field I want to study & 2 & 1 & 16 & 12 & 13 & $3.75(1.06)$ \\
\hline $\begin{array}{l}\text { The RiPS summer program clarified whether graduate school was a good choice } \\
\text { for me }\end{array}$ & 1 & 1 & 11 & 15 & 16 & $4.00(0.96)$ \\
\hline $\begin{array}{l}\text { The RiPS summer program clarified whether I want to pursue a science research } \\
\text { career }\end{array}$ & 2 & 1 & 8 & 16 & 17 & $4.02(1.05)$ \\
\hline The RiPS summer program increased my network of professional STEM contacts & 2 & - & 2 & 13 & 27 & $4.43(0.95)$ \\
\hline
\end{tabular}

aThese questions were not included in the 2019 survey and have an $N=32$.

Note: The same two respondents almost consistently chose "Strongly disagree".

TABLE 3 | Survey items related to academic self-concept.

Item

\begin{tabular}{|c|c|c|c|c|c|c|}
\hline $\begin{array}{l}\text { Strongly } \\
\text { Disagree }\end{array}$ & Disagree & $\begin{array}{l}\text { Neither } \\
\text { Agree or } \\
\text { Disagree }\end{array}$ & Agree & $\begin{array}{c}\text { Strongly } \\
\text { Agree }\end{array}$ & Total & $\begin{array}{c}\text { Mean } \\
\text { (SD) }\end{array}$ \\
\hline
\end{tabular}

I believe that I can accomplish my goal of graduating at my current institution

I have the capability of achieving success in my education After

I believe I am able to help other students be successful in their coursework

I am able to study and be successful in courses that may be hard for me

I believe I am an important part of my school/institution

I will be successful in a career after I graduate

I am confident in my academic knowledge and abilities

$\begin{array}{lcccccc}- & - & 3 & 24 & 16 & 43 & 4.30(0.60) \\ - & - & 2 & 9 & 29 & 40 & 4.68(0.57) \\ - & 2 & 3 & 24 & 14 & 43 & 4.16(0.75) \\ - & - & 1 & 15 & 24 & 40 & 4.58(0.55) \\ - & 2 & 10 & 26 & 5 & 43 & 3.79(0.71) \\ - & - & 4 & 21 & 15 & 40 & 4.28(0.64) \\ - & 3 & 7 & 24 & 9 & 43 & 3.91(0.81) \\ - & - & - & 24 & 16 & 40 & 4.40(0.50) \\ 1 & 3 & 12 & 16 & 11 & 43 & 3.77(1.00) \\ - & 2 & 5 & 13 & 20 & 40 & 4.28(0.88) \\ - & 1 & 9 & 21 & 12 & 43 & 4.02(0.77) \\ - & - & 4 & 15 & 21 & 40 & 4.43(0.68) \\ 1 & 3 & 8 & 22 & 9 & 43 & 3.81(0.93) \\ - & 2 & 2 & 19 & 17 & 40 & 4.28(0.78)\end{array}$

work, if you just gave up then, then nothing matters"

(Cohort 3)

While not part of the original framework guiding this program, elements seen in the student response could be explained through Mindset Theory. Mindset Theory, first described by Carol Dweck, examines the effects on the underlying beliefs about intelligence and how those beliefs impact motivation, responses to challenges, and beliefs about effort (Dweck, 2006). More recently, Dringenberg et al., 2019 have examined "smartness" as an important construct related to but distinct from intelligence. Additionally, some of the changes in participant perception about their ability may also be attributed to the social comparisons that they are able to make during the program, seen in the responses to Question 2 provided in Table 7 .

"I think this helped me be encouraged even more because I've met people who struggle as much as I do" (Cohort 3)

When there is a lack of task-oriented feedback, individuals will compare themselves to their peers to help make determinations about their performance (Dijkstra et al., 
TABLE 4 | Analysis of Survey items related to Academic Self-Concept.

\begin{tabular}{|c|c|c|c|c|}
\hline Item & $\begin{array}{l}\text { Before Participating } \\
\text { Median }\end{array}$ & $\begin{array}{l}\text { After Participating } \\
\text { Median }\end{array}$ & N Pairs & $\begin{array}{l}\text { Wilcoxon } \\
\text { Signed-Rank Z }\end{array}$ \\
\hline $\begin{array}{l}\text { I believe that I can accomplish my goal of graduating at my current } \\
\text { institution }\end{array}$ & 4 & 5 & 39 & $Z=-3.1 ; p=0.002$ \\
\hline I have the capability of achieving success in my education & 4 & 5 & 39 & $Z=-3.2 ; p=0.001$ \\
\hline I believe I am able to help other students be successful in their coursework & 4 & 4 & 39 & $Z=-3.9 ; p<0.001$ \\
\hline I am able to study and be successful in courses that may be hard for me & 4 & 4 & 39 & $Z=-3.3 ; p=0.001$ \\
\hline I believe I am an important part of my school/institution & 4 & 4.5 & 39 & $Z=-3.3 ; p=0.001$ \\
\hline I will be successful in a career after I graduate & 4 & 5 & 39 & $Z=-3.3 ; p=0.001$ \\
\hline I am confident in my academic knowledge and abilities & 4 & 4 & 39 & $Z=-3.5 ; p<0.001$ \\
\hline
\end{tabular}

TABLE 5 | Semi-structured focus group questions.

Question 1

Question 2

Question 3

Question 4

Question 5
Please tell me a little bit about your summer experiences in the RiPS program?

Are you more encouraged or less encouraged about majoring in a STEM program and pursuing a career in science, math of engineering? Explain

In what ways did being a part of a COHORT strengthen or deepen your research experience?

What would you say are the key elements of "being a good scientist"? What does a good scientist "look like" to you? What have you found to be the hardest part of studying STEM? The easiest? The most exciting?

TABLE 6 | Themes mentioned in the focus group discussion in response to Question 4.

Question 4: What would you say are the key elements of "being a good scientist"? What does a good scientist "look like" to you?

Theme

Number of Times Mentioned

\begin{tabular}{|c|c|c|c|c|}
\hline & Cohort 1 & Cohort 2 & Cohort 3 & Tota \\
\hline Patience/persistence/determination & 6 & 1 & 2 & 9 \\
\hline Interest/curiosity/passion for topic & 4 & 1 & & 5 \\
\hline Problem-solving & 2 & & 1 & 3 \\
\hline Receptive of failure/mistakes & & 1 & 2 & 3 \\
\hline Effective communication/collaboration & & 1 & 2 & 3 \\
\hline Careful (adheres to lab safety protocols) & & 2 & & 2 \\
\hline Time management & 1 & & & 1 \\
\hline Positive attitude & 1 & & & 1 \\
\hline Realizing your potential & 1 & & & 1 \\
\hline Calm under pressure & & 1 & & 1 \\
\hline Detail-oriented & & 1 & & 1 \\
\hline Ethical/honest & & 1 & & 1 \\
\hline Responsible & & 1 & & 1 \\
\hline Be yourself & & 1 & & 1 \\
\hline Scientists can be from any racial/cultural background & & 1 & & 1 \\
\hline Professional, but are also human beings & & & 1 & 1 \\
\hline
\end{tabular}

2008). In academic settings, this can primarily be through grades but students may also look for a wide-range of behaviors to better understand and make judgements about their performance such as how long others studied or how quickly someone finished an exam (Dijkstra et al., 2008; Garcia et al., 2013). In traditional academic settings, the cues that students receive are often ambiguous and students may create a false sense of their ability (positive or negative). Secules et al., 2018 have looked at "Engineering Ability" as a culturally constructed idea that can lead students to make judgements about not being "cut out" for engineering. However, in an immersive experience such as the RIPS program, students can't make as many assumptions about student behavior; they see it all. They also receive significant task-oriented feedback and support compared to the traditional academic setting, which allows them to create a positive avenue to view effort and challenges as a path towards mastery.

Sense of belonging is increased along with self-efficacy. The question, "I believe I am an important part of my school/ institution," had the largest mean increase in the retrospective survey. This is very interesting as the students all came from several different institutions.

Some of the themes that arose in question 1 of the focus group were that either the mentor/research team cared about the 
TABLE 7 | Themes mentioned in the focus group discussion in response to Question 2.

Question 2: Are you more encouraged or less encouraged about majoring in a STEM program and pursuing a career in science, math of engineering? Explain

Theme

Number of Times Mentioned

\begin{tabular}{|c|c|c|c|c|}
\hline & \\
\hline & Cohort 1 & Cohort 2 & Cohort 3 & Total \\
\hline More encouraged & 8 & 1 & 7 & 16 \\
\hline Neither more nor less encouraged & & & 2 & 2 \\
\hline
\end{tabular}

Explanation

Better understanding of future direction

Positive experience with mentor and/or lab mates

Helped decide on my major

Being exposed to what others do and experience in the field/major is encouraging

Hands-on experience

Feel comfortable/encouraged about continuing education

Learned value of good communication skills

Learned independent study skills

Interest in non-research lab-based career

Still unsure of direction in terms of major/career

May change major

Questioned/reconsidered major

Mentors were unavailable for a period(s) of time

More knowledgeable

Overwhelmed with the variety of major/career path options

Pressure to choose major quickly due to personal reasons or family obligations

Enjoys service-oriented side of STEM

Professional networking

No graduate student/other staff member support

Graduate student support helped

Learned independent research skills

\begin{tabular}{|c|c|c|c|}
\hline \multirow[t]{2}{*}{5} & & & 5 \\
\hline & & 5 & 5 \\
\hline \multirow[t]{2}{*}{4} & & & 4 \\
\hline & & 4 & 4 \\
\hline 3 & & 2 & 5 \\
\hline \multirow[t]{8}{*}{3} & & & 3 \\
\hline & & 3 & 3 \\
\hline & & 3 & 3 \\
\hline & 2 & & 2 \\
\hline & 2 & & 2 \\
\hline & 2 & & 2 \\
\hline & & 2 & 2 \\
\hline & & 2 & 2 \\
\hline \multirow[t]{8}{*}{1} & & & 1 \\
\hline & 1 & & 1 \\
\hline & 1 & & 1 \\
\hline & & 1 & 1 \\
\hline & & 1 & 1 \\
\hline & & 1 & 1 \\
\hline & & 1 & 1 \\
\hline & & 1 & 1 \\
\hline
\end{tabular}

student or that the students had positive experience with and received support from their peers. The support from the mentor/ research team was primarily discussed by Cohort 1 , as shown in Table 8.

"They cared a lot about what we had to say and if we didn't understand they explained it until we got it." (Cohort 1)

These findings can also be related back to Framework 2: Engagement theory. The creation of a supportive environment through mentors and peers increases not self-efficacy but drove interest and performance.

The support coming from peers was discussed across cohorts, as seen in Table 9. Connecting as a cohort and building academic skills may also be important because it builds on the confidence and accomplishment gained by a research experience. Which maps to both Framework 2: Engagement theory and Framework 3: Cumulative advantage theory. Positive research experiences may be more important than a perfect research interest match.

The survey results (Table 3) for academic self-concept showed that all items increased in the reflective surveys. Furthermore, in Table 4, it is shown that all items showed a statistically significant increase (most items $p=<0.001$ ) when reflecting on before and after participation.

Of particular note were large average increases for "I am able to study and be successful in courses that may be hard for me" and "I believe I am an important part of my school/ institution.” Focus group responses to Question 1-4 elicited responses related to academic self-concept. The importance of patience and persistence was noted across the cohorts and helps elucidate why students increased their rating of "I am able to study and be successful in courses that may be hard for me." This is in line with Framework 1: Retention theory/ integration theory and further demonstrates the relationship between resilience, identity, and academic self-concept.

\section{RQ 2: Does a Summer Research Program With Integrated University Experiences Increase STEM Interest and STEM Identity?}

The results from the surveys, shown in Tables 10, 11, demonstrated a significant increase in STEM identity.

The STEM identity increase is nuanced. While there is an increase in the mean for the question, "I see myself as a science or math person," Table 11 shows that this increase is not statistically significant $(p=0.073)$. All other items in the STEM identity section of the survey had statistically significant increases.

There is a barrier between being a person that tests well in math or science and actually seeing yourself as someone who can become accomplished and succeed in STEM. Being able to communicate with others about interests in STEM and knowledge acquired is also discussed by students in Cohort 2 and 3 in response to Question 4: What would you say are the key elements of "being a good scientist"? What does a good scientist "look like" to you? (Table 6). 
TABLE 8 | Themes mentioned in the focus group discussion in response to Question 1.

Question 1: Please tell me a little bit about your summer experiences in the RiPS program?

Theme

Number of Times Mentioned

Cohort 1 Cohort 2 Cohort 3 Total

Gained a deeper understanding of field/discipline and those working in the field

Mentor/research team cared about me/helped me

Valuable career exploration

Provided hands on experience

Networked/met new people

Personal growth/recognizing one's potential

Valuable team experience

Unique internship experience

Seminars could be improved (complaints include: seminars are too long; seminars conflicted with lab time; some seminar topics weren't as relevant to undergrads)

Experienced challenges with the dorm (beds, smell, food, weak wi-fi signal)

Positive social experience/meeting new people/friendships

Mentors were unavailable for a period(s) of time

Hands-on experience (including management experience)

Was not assigned to mentor in STEM field of interest

No graduate student/other staff member support

Explore majors

Participating lead to a job opportunity

Campus/library tours were helpful

Did not find all seminar topics to be immediately useful

Positive experience with mentor

Too much lab work towards end of program (took away from poster presentation)

Multiple mentors/experiences

Would like to have received preparatory/orientation like materials before starting RiPS (i.e. learn where they will be placed;

preparatory reading list about research topic)

Graduate student support helped

Productive way to spend the summer

Sense of accomplishment

\begin{tabular}{|c|c|c|c|}
\hline 6 & & & 6 \\
\hline 5 & & & 5 \\
\hline 2 & & 3 & 5 \\
\hline 4 & & & 4 \\
\hline 3 & & & 3 \\
\hline 1 & & 2 & 3 \\
\hline 2 & & & 2 \\
\hline 2 & & & 2 \\
\hline & 2 & & 2 \\
\hline & 2 & & 2 \\
\hline & 2 & & 2 \\
\hline & 2 & & 2 \\
\hline & 2 & & 2 \\
\hline & 2 & & 2 \\
\hline & 2 & & 2 \\
\hline & & 2 & 2 \\
\hline 1 & & & 1 \\
\hline & 1 & & 1 \\
\hline & 1 & & 1 \\
\hline & 1 & & 1 \\
\hline & 1 & & 1 \\
\hline & 1 & & 1 \\
\hline & 1 & & 1 \\
\hline & 1 & & 1 \\
\hline & & 1 & 1 \\
\hline & & 1 & 1 \\
\hline
\end{tabular}

TABLE 9 | Themes mentioned in the focus group discussion in response to Question 3.

Question 3:In what ways did being a part of a COHORT strengthen or deepen your research experience?

Number of Times Mentioned

Theme

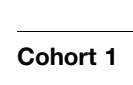

2

Members of cohort provided support

Being with others of a similar cultural background increased comfort level when on campus

Did not spend as much time together as a whole group (due to program scheduling)

Team motivated me

Sense of belonging

Experience may have been different without cohort members

Shared information about the different fields STEM fields

Coming from diverse backgrounds led to a diverse experience

1
1
1
Positive experience

\section{Cohort 2}

Cohort 3

Total

2

1
2

6

6

2

2

"You could be the most brilliant person in the world and have discovered something really cool, but if you can't explain it to anyone, no one knows what the hell you just did or why it matters, what good does it do anyone?" (Cohort 3)

"The importance of not only being able to get the results, but being able to explain them in a way that you can teach it to other people and be able to spread it to them and let them see the importance of the information that you gathered." (Cohort 3)
Cohort 1 did not mention the need for more effective communication but as previously mentioned all cohorts discussed the needs for patience and persistence. Cohort 1 also discussed the need for interest and curiosity.

"The person has to be curious and they should be able to dig deeper into their subject." (Cohort 1)

"You also have to have an interest for what you're doing. You have to have that passion for learning." (Cohort 1) 
TABLE 10 | Items related to STEM identity.

Item

Strongly Disagree Neither Agree Strongly Total Mean

$\begin{array}{lll}\text { Disagree } & \text { Agree or } & \text { Agree }\end{array}$

I see myself as a science or math person

I Have a lot of pride in my accomplishments in science/math When it comes to scientific Knowledge and understanding I can compete at
the highest levels

I enjoy talking about science and/or math with others

I am active in organizations or groups related to science, math, or engineering

I am interested in reading websites, magazines or books about scientific issues

I am interested in helping others use science

I am interested in the way science and engineering help people

Disagree

$\begin{array}{lllllllllllll} & \text { After } & 1 & 4.54 & (0.84)\end{array}$

TABLE 11 | Analysis of responses to items related to STEM identity.

\begin{tabular}{|c|c|c|c|c|}
\hline & $\begin{array}{l}\text { Before Participating } \\
\text { Median }\end{array}$ & $\begin{array}{l}\text { After participating } \\
\text { Median }\end{array}$ & $\begin{array}{l}\mathbf{N} \\
\text { Pairs }\end{array}$ & $\begin{array}{l}\text { Wilcoxon } \\
\text { Signed-Rank Z }\end{array}$ \\
\hline I see myself as a science or math person & 4 & 5 & 40 & $Z=-1.8 ; p=0.073$ \\
\hline I Have a lot of pride in my accomplishments in science/math & 4 & 5 & 40 & $Z=-3.7 ; p<0.001$ \\
\hline $\begin{array}{l}\text { When it comes to scientific Knowledge and understanding I can compete at } \\
\text { the highest levels }\end{array}$ & 3 & 4 & 39 & $Z=-4.2 ; p<0.001$ \\
\hline I enjoy talking about science and/or math with others & 4 & 5 & 40 & $Z=-3.6 ; p<0.001$ \\
\hline I am active in organizations or groups related to science, math, or engineering & 4 & 4 & 40 & $Z=-3.8 ; p<0.001$ \\
\hline I am interested in reading websites, magazines or books about scientific issues & 4 & 4 & 40 & $Z=-3.9 ; p<0.001$ \\
\hline I am interested in helping others use science & 4 & 5 & 40 & $Z=-4.0 ; p<0.001$ \\
\hline I am interested in the way science and engineering help people & 4 & 5 & 40 & $Z=-3.6 ; p<0.001$ \\
\hline
\end{tabular}

The interest in STEM was already there, however students needed to understand the importance of scientific communication and have confidence in their ability to be part of the process to strongly agree with statements such as, "I am interested in reading websites, magazines or books about scientific issues", "I am interested in helping others use science", and "I enjoy talking about science and/or math with others." In response to question 1: "Please tell me a little bit about your summer experiences in the RiPS program?" in the focus groups students also discussed the value of gaining a deeper understanding of the field as well as hands-on experience.

\footnotetext{
"So seeing everything how it actually works and what it all actually means to begin with and how deep it actually goes to understand everything in my field I'm trying to go into." (Cohort 1)
}

These results can also be explained through our guiding framework of cumulative advantage theory. Students needed to gain academic, communication, and research skills to fully recognize and express their interests. The majority of students expressed feeling more encourage after participating in the program. The explanation for their response to Question 2: "Are you more encouraged or less encouraged about majoring in a STEM program and pursuing a career in science, math of engineering? Explain," included understanding their future direction, building their skills, getting hands-on experience, and positive experiences with their mentor and peers, as shown in Table 7.

"When you are able to experience the forefront of research in an area of study, you can understand where you maybe best fit within your study" (Cohort 1)

"I feel more comfortable now so I do plan on coming here during the fall. So I think it was very helpful for deciding whether or not to major in biochemistry." (Cohort 1)

"I worked a lot with my advisor. That was really great. He was really good at what he does." (Cohort 3)

Results from this work are in alignment with Graham's work surrounding persistence (Graham, 2013) and Retention theory. His work emphasized the importance of both learning and professional identification as key to persistence in STEM. Responses to question 5, shown in Table 12, also explain the 
TABLE 12 | Themes mentioned in the focus group discussion in response to Question 5.

Question 5: What have you found to be the hardest part of studying STEM?

Theme

\begin{tabular}{lccc}
\multicolumn{4}{c}{ Number of Times Mentioned } \\
\hline Cohort 1 & Cohort 2 & Cohort 3 & Total
\end{tabular}

Lack of background knowledge

Complexity of STEM/STEM content

5

Lab experiments (e.g., minute details, failed results)

Lack of research/lab experience

Scientific reasoning

Self-motivation

Steep learning curve from high school to community college to the university

Time management

Choosing a STEM major/career

Learning critical thinking skills

Many different ways to do things

Not being \#1/competitive

Shadowing mentor rather than assisting (not being able to engage in experiential process)

Understanding how the experience is relevant to the future

2

2

2

\section{The easiest part?}

Support from peers and faculty/staff

Collegial learning and working environment

Program was well-organized and provided necessities (e.g., room and board, food, monetary support)

Positive social environment

Understanding/when it all comes together in your mind

Following the plan you have created

Getting into a routine after getting used to the program

Learning overlaps between projects (synergy)

Attending seminars

Looking forward to the future

$\begin{array}{lll}6 & 6 \\ 4 & & 4 \\ 3 & & 3 \\ 2 & & 2 \\ 2 & & 2 \\ 1 & & 1 \\ 1 & 1 & 1 \\ & & 1 \\ & 1 & 1 \\ & 1 & 1\end{array}$

\section{The most exciting part?}

Lab work (e.g., knowledge gains, groundbreaking discoveries, state of the art lab equipment)

Sense of accomplishment (poster presentation)

New STEM knowledge/skills

Professional networking

Exploring future study/career options or paths

Preview of the future (whether it is career/major prospects or moving to K-State)

Product testing/development

Enjoyable seminars

Experiencing campus life

Moment it all came together/understanding

$\begin{array}{llll}2 & 4 & 3 & 6 \\ 3 & & 3 & 6 \\ 3 & 2 & & 5 \\ 3 & 5 & 3 & 5 \\ & & & 3 \\ 1 & 2 & 1 & 3 \\ 1 & & & 1 \\ & & & 1 \\ & & & 1\end{array}$

\section{Other}

Lab schedule was not flexible enough

Pleasantly surprised by schedule flexibility (general)

Please continue program with other students

3

2

2

$\begin{array}{rl}2 & 2 \\ 2 & 2\end{array}$

$\begin{array}{ll}1 & 1 \\ 1 & 1\end{array}$

1

increase in the sense of pride and accomplishment. Students were excited about getting to be a part of groundbreaking discoveries and learning new skills.

"I think one of the most exciting things is when you're researching something like they kind of said is like groundbreaking, something that nobody's really knows about." (Cohort 2)

All items in Table 10 showed an increase in STEM identity. In the response to questions 2,4 , and 5 during the focus groups students also discussed themes related to STEM identity. It is interesting that Question 4: "What would you say are the key elements of "being a good scientist"? What does a good scientist "look like" to you?" elicited rich responses related to both academic self-concept and STEM identity.

\section{Program Impact}

Since the beginning of the program, 5 years ago, 39/41 (95\%) of community college participants have transferred to a four-year institution. This is exceptional as a recent report from the National Student Clearinghouse Research Center noted that from a 2010 cohort of 852,439 students, $31.5 \%$ of students transferred to a fouryear institution within six-years (Shapiro, 2017). 


\section{LESSONS LEARNED, RECOMMENDATIONS AND FUTURE WORK}

Coordination of this program over the past 5 years has resulted in several lessons that are noted below.

\section{Research Supplementation}

Being mindful that we were working with novice undergraduate research students from underrepresented groups, we decided to create additional support systems to aid in student success. Program coordinators and participants met twice per week to discuss topics that supplemented individual student experiences. Content for the weekly seminar was developed using the Entering Research curriculum (Branchaw, 2020). This curriculum helps novice undergraduate students navigate the process of conducting research, develop mentoring relationships and helps to create a learning community among program participants (Balster, 2010). Seminars were designed to foster student engagement and time was intentionally set aside for cohort building.

\section{Cohort Activities}

Throughout the program, various social activities were scheduled to help students develop relationships among themselves in an informal setting. Activities included bowling, playing team sports together, group game nights or field trips to local attractions (ex. zoo, botanical garden etc.). Since the majority of program participants were first-generation and often from underrepresented backgrounds, we wanted to create informal spaces for them to be themselves and talk with each other. Additionally, some of these activities provided an opportunity for students to leave campus and explore the town. This was more relevant to our community college students as they were thinking of potentially transferring to a four-year institution.

\section{Collaborations With Other Summer Programs}

Building relationships with other campus groups can aid in the success of an individual program. During a typical summer, there are several groups on campus that coordinate undergraduate summer research experiences. Coordinators from each group are part of a campus-wide Undergraduate Research Experience Consortium. The group meets once or twice prior to the start of summer programs to learn about program updates and strategically plan group activities. Signature events that all summer undergraduate students were invited to include a BBQ or ice cream social and a field trip to a local federally funded research site. The goal of the group events was to showcase the various undergraduate programs on campus and to have students engage across programs.

\section{Program Staff}

An enthusiastic coordinator who cares about program participants paired with good staff will ensure that students make meaningful and positive connections during their time in the program.
Specific details related to the above program were changed and/or slightly modified each year based on the cohort, availability and engagement by campus partners.

\section{Recommendations and Future Work Enhanced Training Opportunities}

Student participants spend most of their time in their research lab interacting with faculty mentors, graduate students and/or post docs. The quality of the interactions matters. Providing training to faculty and/or graduate students involved in the program would be helpful. Barnet's work indicated that faculty validation of student significantly predicted intent to persist (Barnett, 2010). Additionally, Langhoff noted that encouraging graduate students who interact with program participants to share their academic journey and challenges may help improve the quality of summer research programs for community college students (Langhoff, 2018). Future programming will include more in-depth training for research mentors. Potential training materials may include portions of the Entering Mentoring curriculum (Pfund et al., 2015).

\section{Additional Program Components}

In addition to providing information about the research process and opportunities for social interaction, additional student development opportunities can be offered. These may include information about networking followed by specific networking events. Additionally, early career students such as our community college participants may benefit from resume building workshops and opportunities to explore career interests (Crisp, 2013).

In future work, looking at the cultural construction of "smartness" and ability are relatively new areas of research and topics that can be explored with future cohorts. Additionally, more analysis of available qualitative data could be used for assessing the impact of other elements in the framework that guided the development of this program. For example, while engagement theory is related to both identity and academic self-concept, the quantitative data and preliminary analysis of the qualitative data does not paint a complete picture of which tasks were found meaningful and worthwhile. Coding and categorization of qualitative data may be able to elucidate specific recommendations on the more effective University activities.

\section{DATA AVAILABILITY STATEMENT}

The original contributions presented in the study are included in the article/Supplementary Material, further inquiries can be directed to the corresponding author.

\section{ETHICS STATEMENT}

The studies involving human participants were reviewed and approved by Institutional Review Board of Kansas State University. The patients/participants provided their written informed consent to participate in this study. 


\section{AUTHOR CONTRIBUTIONS}

$\mathrm{BK}, \mathrm{BM}$, and LT contributed to the research design. $\mathrm{BK}$ contributed to the data collection. $\mathrm{AB}, \mathrm{BK}$, and $\mathrm{BM}$ contributed to the data analysis. All authors contributed to the discussion and writing of the manuscript.

\section{REFERENCES}

Allison, P. D., Long, J. S., and Krauze, T. K. (1982). Cumulative Advantage and Inequality in Science. Am. Sociological Rev. 47, 615-625. doi:10.2307/2095162

Allison, P. D., and Stewart, J. A. (1974). Productivity Differences Among Scientists: Evidence for Accumulative Advantage. Am. Sociological Rev. 39, 596-606. doi:10.2307/2094424

Alva, S. A. (1991). Academic Invulnerability Among Mexican-American Students: The Importance of Protective Resources and Appraisals. Hispanic J. Behav. Sci. 13, 18-34. doi:10.1177/07399863910131002

Astin, A. W. (1982). In Minorities in American Higher Education: Recent Trends, Current Prospects, and Recommendations. San Francisco, CA: Jossey-Bass.

Astin, A. W. (1993). What Matters in College? Four Critical Years Revisited. San Francisco, CA: Jossey-Bass.

Balster, N., Pfund, C., Rediske, R., and Branchaw, J. (2010). Entering Research: A Course that Creates Community and Structure for Beginning Undergraduate Researchers in the STEM Disciplines. CBE Life Sci. Educ. 9 (Summer 2010), 108-118. doi:10.1187/cbe.09-10-0073

Branchaw, J. L. (2020). Entering Research: A Curriculum to Support Undergraduate and Graduate Trainees. 2nd ed. New York: Macmillan.

Barnett, E. A. (2010). Validation Experiences and Persistence Among Community College Students. Rev. Higher Edu. 34 (2), 193-230. doi:10.1353/rhe.2010.0019

Carlone, H. B., and Johnson, A. (2007). Understanding the Science Experiences of Successful Women of Color: Science Identity as an Analytic Lens. J. Res. Sci. Teach. 44 (8), 1187-1218. doi:10.1002/tea.20237

Chang, M. J., Eagan, M. K., Lin, M. H., and Hurtado, S. (2011). Considering the Impact of Racial Stigmas and Science Identity: Persistence Among Biomedical and Behavioral Science Aspirants. J. Higher Educ. 82 (5), 564-596. doi:10.1353/ jhe. 2011.0030

Crisp, G., and Taggart, A. (2013). Community College Student Success Programs: A Synthesis, Critique, and Research Agenda. Community Coll. J. Res. Pract. 37 (2), 114-130. doi:10.1080/10668920903381847

Davis, C.-S. G., and Finelli, C. J. (2007). Diversity and Retention in Engineering. New Dir. Teach. Learn. 2007, 63-71. doi:10.1002/tl.287

DePass, A. L., and Chubin, D. E. (2008). Understanding Interventions that Encourage Minorities to Pursue Research Careers: Building a Community of Research and Practice. Retrieved from: www.cossa.org/diversity/reports/ 08Understanding_Interventions.pdf.

Dijkstra, P., Kuyper, H., Van der Werf, G., Buunk, A. P., and van der Zee, Y. G. (2008). Social Comparison in the Classroom: A Review. Rev. Educ. Res. 78 (4), 828-879. doi:10.3102/0034654308321210

Dillman, D. A., Smyth, J. D., and Christian, L. M. (2014). Internet, Phone, Mail, and Mixed-Mode Surveys: The Tailored Design Method. Hoboken, NJ: John Wiley \& Sons.

DiPrete, T. A., and Eirich, G. M. (2006). Cumulative Advantage as a Mechanism for Inequality: A Review of Theoretical and Empirical Developments. Annu. Rev. Sociol. 32, 271-297. doi:10.1146/annurev.soc.32.061604.123127

Dringenberg, E., Kramer, A., and Secules, S. (2019). Smartness in Engineering Culture: An Interdisciplinary Dialogue. Tampa, FL: American Society for Engineering Education Annual Conference and Exposition.

Dweck, C. S. (2006). Mindset: The New Psychology of success. New York, NY: Random House LLC.

Dyer-Barr, R. (2013). "What Works in STEM Intervention Programs (SIPs) for Underrepresented Minority Undergraduates: Perspectives from SIP Administrators," in ASQ Advancing the STEM Agenda Conference (Grand Rapids, MI). Retrieved from: http://rube.asq.org/edu/2013/04/best-practices/ what-works-in-stem-intervention-programs-for-urm-undergraduates.pdf.

\section{FUNDING}

This work was funded by the National Science Foundation Awards \#1305059: Pathways to STEM: Kansas Louis Stokes Alliance for Minority Participation and \#1817537: Louis Stokes STEM Pathways Implementation-Only Alliance: Kansas Pathways to STEM.

Eagan, K., Hurtado, S., Figueroa, T., and Hughes, B. (2014). "Examining STEM Pathways Among Students Who Begin College at Four-Year Institutions," in Commissioned Paper Prepared for the Committee on Barriers and Opportunities in Completing 2- and 4-Year STEM Degrees (Washington, DC: National Academy of Sciences). Available at: http://sites.nationalacademies.org/cs/ groups/dbassesite/documents/webpage/dbasse_088834.pdf (Accessed April, 2015).

Eagan, M. K., Hurtado, S., Chang, M. J., Garcia, G. A., Herrera, F. A., and Garibay, J. C. (2013). Making a Difference in Science Education: The Impact of Undergraduate Research Programs. Am. Educ. Res. J. 50 (4), 683-713. doi:10.3102/0002831213482038

Estrada, M., Burnett, M., Campbell, A. G., Campbell, P. B., Denetclaw, W. F., Gutiérrez, C. G., et al. (2016). Improving Underrepresented Minority Student Persistence in STEM. CBE Life Sci. Educ. 15 (3), 1-10. doi:10.1187/cbe.16-010038

Garcia, S. M., Tor, A., and Schiff, T. M. (2013). The Psychology of Competition: A Social Comparison Perspective. Perspect. Psychol. Sci. 8 (6), 634-650. doi:10.1177/1745691613504114

George-Jackson, C., and Rincon, B. (2011). Establishing Legitimacy Among STEM Intervention Programs: The Need for Evaluation. Retrieved from: http://asq. org/edu/2011/06/benchmarking/establishing-legitimacy-among-stem-interventionprograms-the-need-for-ealuation.pdf.

Ghee, M., Keels, M., Collins, D., Neal-Spence, C., and Baker, E. (2016). Fine-tuning Summer Research Programs to Promote Underrepresented Students' Persistence in the STEM Pathway. CBE Life Sci. Educ. 15 (ar28(Fall)), 1-11. doi:10.1187/cbe.16-01-0046

Gonzalez, R., and Padilla, A. M. (1997). The Academic Resilience of Mexican American High School Students. Hispanic J. Behav. Sci. 19 (3), 301-317. doi:10.1177/07399863970193004

Graham, M. J., Frederick, J., Byars-Winston, A., Hunter, A. B., and Handelsman, J. (2013). Science Education. Increasing Persistence of College Students in STEM. Science 341, 1455-1456. doi:10.1126/science.1240487

Grauer, B., Thurston, L. P., and Montelone, B. A. (2015). "KS-LSAMP Pathways to STEM: A System Approach to Minority Participation,” in STEM Paper Presented at 2015 ASEE Annual Conference \& Exposition (Seattle, Washington), 24389.

Hernandez, J. C., and Lopez, M. A. (2004). Leaking Pipeline: Issues Impacting Latino/a College Student Retention. J. Coll. Student Retention: Res. Theor. Pract. 6 (1), 37-60. doi:10.2190/fbly-0uaf-ee7w-qjd2

Hurtado, S., Cabrera, N. L., Lin, M. H., Arellano, L., and Espinosa, L. L. (2009). Diversifying Science: Underrepresented Student Experiences in Structured Research Programs. Res. High Educ. 50 (50), 189-214. doi:10.1007/s11162-008-9114-7

Hurtado, S., and Carter, D. F. (1997). Effects of College Transition and Perceptions of the Campus Racial Climate on Latino College Students' Sense of Belonging. Sociol. Edu. 70 (4), 324-345. doi:10.2307/2673270

Ishiyama, J. (2001). Undergraduate Research and the success of First-Generation, LowIncome College Students. Council on Undergraduate Research Quarterly 21 (3), 36-41.

Kearsley, G. (1997). The Virtual Professor: A Personal Case Study. Retrieved from: http://home.sprynet.com/ gkearsley/virtual.html.

Kearsley, G., and Shneiderman, B. (1998). Engagement Theory: A Framework for Technology-Based Teaching and Learning. Educ. Tech. 38 (5), p20-23.

Krueger, R. A., and Casey, M. A. (2009). Focus Groups: A Practical Guide for Applied Research. Los Angeles CA: SAGE.

Langhoff, N. E. (2018). Student Perceptions of a Summer Research Internship Program for Underrepresented Community College Engineering Students. Salt Lake City, UT: ASEE Annual Conference \& Exposition.

Lent, R. W., Brown, S. D., and Larkin, K. C. (1986). Self-efficacy in the Prediction of Academic Performance and Perceived Career Options. J. Couns. Psychol. 33 (3), 265-269. doi:10.1037/0022-0167.33.3.265 
Lopatto, D. (2004). Survey of Undergraduate Research Experiences (SURE): First Findings. Cell Biol Educ 3 (Winter), 270-277. doi:10.1187/cbe.04-07-0045

Lopatto, D. (2007). Undergraduate Research Experiences Support Science Career Decisions and Active Learning. CBE Life Sci. Educ. 6 (Winter), 297-306. doi:10.1187/cbe.07-06-0039

Lopatto, D. (2003). The Essential Features of Undergraduate Research. Counc. Undergraduate Res. Q. 23 (3), 139-142.

Luzzo, D. A., Hasper, P., Albert, K. A., Bibby, M. A., and Martinelli, E. A. J., Jr. (1999). Effects of Self-Efficacy-Enhancing Interventions on the Math/science Self-Efficacy and Career Interests, Goals, and Actions of Career Undecided College Students. J. Couns. Psychol. 46 (2), 233-243. doi:10.1037/00220167.46.2.233

Mabrouk, P. A., and Peters, K. (2000). Student Perspectives on Undergraduate Research (UR) Experiences in Chemistry and Biology. Retrieved from: http:// www.chem.vt.edu/confchem/2000/a/mabrouk/mabrouk.htm.

Nagda, B. A., Gregerman, S. R., Jonides, J., von Hippel, W., and Lerner, J. S. (1998). Undergraduate Student-Faculty Research Partnerships Affect Studen Retention. Rev. Higher Edu. 22 (1), 55-72. doi:10.1353/rhe.1998.0016

National Center for Education Statistics (2013). STEM Attrition: College Students' Paths into and Out of STEM Fields. Washington, DC: NCES 2014-001. http:// nces.ed.gov/pubs2014/2014001rev.pdf.

Nora, A. (2003). "Access to Higher Education for Hispanic Students: Real or Illusory?," in The Majority in the Minority: Expanding the Representation of Latina/o Faculty, Administrators, and Students in Higher Education. Editors J. Castellanos and L. Jones (Sterling, VA: Stylus Publishing), 47-70.

Nora, A., Barlow, E., and Crisp, G. (2005). "Student Persistence and Degree Attainment beyond the First Year in College: The Need for Research," in College Student Retention: Formula for Student success. Editor A. Seidman (Westport, CT: Praeger), 130-153.

Olson, S., and Labov, J. B. (2012). Community Colleges in the Evolving STEM Education Landscape: Summary of a summit. Washington, DC: The National Academy Press.

Patton, M. H. (2020). Community College Undergraduate Research Experience Summit Proceedings Report. Washington, D.C.: American Association of Community Colleges.

Pfund, C., Branchaw, J., and Handelsman, J. (2015). Entering Mentoring. W. H. Freeman.

Sabatini, D. A. (1997). Teaching and Research Synergism: The Undergraduate Research Experience. J. Prof. Issues Eng. Educ. Pract. 123 (3), 98-102. doi:10.1061/(asce)1052-3928(1997)123:3(98)

Schoonenboom, J., and Johnson, R. B. (2017). How to Construct a Mixed Methods Research Design. Köln Z. Soziol. 69, 107-131. doi:10.1007/ s11577-017-0454-1

Secules, S., Gupta, A., Elby, A., and Turpen, C. (2018). Zooming Out from the Struggling Individual Student: An Account of the Cultural Construction of
Engineering Ability in an Undergraduate Programming Class. J. Eng. Educ. 107 (1), 56-86. doi:10.1002/jee.20191

Sedlacek, W. (1989). Noncognitive Indicators of Student success. J. Coll. Admissions 125, 2-10. doi:10.1177/1521025116666539

Seymour, E. H.-B. (2004). Establishing the Benefits of Research Experiences for Undergraduates in the Sciences. Sci. Edu. 1 (88), 493-534. doi:10.1002/ sce.10131

Shapiro, D. D. (2017). Tracking Transfers: Measures of Effectiveness in Helping Community College Students Complete Bachelor's Degrees (Signature Report No. 13). Herndon, VA: National Student Clearing house Research Center.

Spady, W. G. (1970). Dropouts from Higher Education: An Interdisciplinary Review and Synthesis. Interchange 1 (1), 64-85. doi:10.1007/bf02214313

The National Academies of Sciences (2011). Expanding Minority Participation: America's Science and Technology Talent at the Crossroads. Washington, DC: National Academy Press.

Tinto, V. (1997). Classrooms as Communities. J. Higher Edu. 68, 599-623. doi:10.1080/00221546.1997.11779003

Tinto, V. (1975). Dropout from Higher Education: A Theoretical Synthesis of Recent Research. Rev. Educ. Res. 45 (1), 89-125. doi:10.3102/ 00346543045001089

Tsapogas, J. (2004). The Role of Community Colleges in the Education of Recent Science and Engineering Graduates. Arlington, VA: Division of Science Resources Statistics, National Science Foundation.

Zuckerman, H. (1988). "Accumulation of Advantage and Disadvantage: The Theory and its Intellectual Biography," in Robert K. Merton and Contemporary Sociology. Editors C. Mongardini and S. Tabboni (New York: Trans. Publ.), 139-162.

Conflict of Interest: The authors declare that the research was conducted in the absence of any commercial or financial relationships that could be construed as a potential conflict of interest.

Publisher's Note: All claims expressed in this article are solely those of the authors and do not necessarily represent those of their affiliated organizations, or those of the publisher, the editors and the reviewers. Any product that may be evaluated in this article, or claim that may be made by its manufacturer, is not guaranteed or endorsed by the publisher.

Copyright $\odot 2021$ Betz, King, Grauer, Montelone, Wiley and Thurston. This is an open-access article distributed under the terms of the Creative Commons Attribution License (CC BY). The use, distribution or reproduction in other forums is permitted, provided the original author(s) and the copyright owner(s) are credited and that the original publication in this journal is cited, in accordance with accepted academic practice. No use, distribution or reproduction is permitted which does not comply with these terms. 